\title{
EXPLORING LEGAL BORDERLANDS: INTRODUCING THE THEME
}

\author{
PEDRO RUBIM BORGES FORTES ${ }^{1}$ \\ IOANNIS KAMPOURAKIS ${ }^{2}$
}

\begin{abstract}
The theme Exploring Legal Borderlands has been used as an inspiration for contemporary research at the Centre for Socio-Legal Studies (CSLS) at the University of Oxford since 2015, when Naomi Creutzfeldt and Petra Mahy organised a stream at the Socio-Legal Studies Association (SLSA) Conference at the University of Warwick. Importantly, this research agenda remains relevant and a series of papers have been presented at the subsequent annual SLSA conferences in Lancaster (2016), Newcastle (2017), Bristol (2018), and more recently in Leeds (2019). In the last five years, various scholars presented their innovative interdisciplinary research at this stream and it remained organized by junior scholars affiliated with CSLS and the University of Oxford. However, the definition of legal borderlands was not provided in a clear statement. Legal borderlands, as understood in this issue, are about this ambiguity inherent in a world of multiple normative orders. The following issue's originality consists in the conceptual exploration of the idea of legal borderlands. In an increasingly interconnected world of diverse and often conflicting normative orders, such research is particularly relevant. As far as it concerns this article, in addition to this introduction, Section II briefly examines the legal boundaries and the dichotomy between (il)legality and a-legality. Section III focuses on normative pluralism and the development of juridical orders. Section IV discusses global regulation as an expansion of legal borderlands. Section $\mathrm{V}$ brings concluding remarks and summarizes the articles that follow.
\end{abstract}

KEYWORDS: Legal Borderlands; multiple normative orders; Socio-Legal Studies.

${ }^{1}$ DPHIL (Oxford), JSM (Stanford), LLM (Harvard), MBE (Coppe-UFRJ), BA (PUC-Rio), LLB (UFRJ). Contato: pfortes@alumni.stanford.edu.

2 Career Development Postdoctoral Fellow, Centre for Socio-Legal Studies, University of Oxford. Contato: ioannis.kampourakis@csls.ox.ac.uk. 


\section{INTRODUCTION}

The theme Exploring Legal Borderlands has been used as an inspiration for contemporary research at the Centre for Socio-Legal Studies (CSLS) at the University of Oxford since 2015, when Naomi Creutzfeldt and Petra Mahy organised a stream at the Socio-Legal Studies Association (SLSA) Conference at the University of Warwick. ${ }^{3}$ Importantly, this research agenda remains relevant and a series of papers have been presented at the subsequent annual SLSA conferences in Lancaster (2016), Newcastle (2017), Bristol (2018), and more recently in Leeds (2019). In the last five years, various scholars presented their innovative interdisciplinary research at this stream and it remained organized by junior scholars affiliated with CSLS and the University of Oxford. However, the definition of legal borderlands was not provided in a clear statement. In the initial call for papers, Naomi Creutzfeldt and Petra Mahy highlighted the "uncertainties and interactivity of legal borderlands", providing examples such as the "division between the formal and the informal, law and nonlaw and jurisdictional boundaries" . ${ }^{4}$ According to them, legal borderlands are not "clearly defined or static", falling into grey areas. ${ }^{5}$ Such grey areas are primarily constituted by the continuous development of social norms and practices, as well as by the malleable - and subject to spatial and temporal variations - understanding of the 'legal'. Finally, the purpose of this stream was also to display empirical and interdisciplinary methods of socio-legal research. ${ }^{6}$

Borders, by definition, imply the existence of some discontinuity. Yet, their significance is not necessarily this of an abrupt cut between two incommensurable realities. Rather, borders can also entail the ambiguity of a zone where one order of things morphs into another. Legal borderlands, as understood in this issue, are about this ambiguity inherent in a world of multiple normative orders. Ambiguity might result from overlapping jurisdictions and conflict of laws or it might be the consequence of a disjunction between legal and non-legal normative orders. In conditions of globalisation, when situations of 'interlegality ${ }^{7}$ have multiplied due to transnational orders, legal borderlands become extremely significant and consequential for the underlying normative structures that order societies,

3 https://warwick.ac.uk/fac/soc/law/research/events/conferences/slsa/streams/elbeaia/ (checked in 16.09.2019).

4 Idem.

${ }^{5}$ Idem.

6 Idem.

7 Boaventura de Sousa Santos, 'Law: A Map of Misreading. Toward a Postmodern Conception of Law' (1987) 14(3) Journal of Law and Society 279, 298. 
economies, and individual lives. The following issue's originality consists in the conceptual exploration of the idea of legal borderlands. In an increasingly interconnected world of diverse and often conflicting normative orders, such research is particularly relevant. As far as it concerns this article, in addition to this introduction, Section II briefly examines the legal boundaries and the dichotomy between (il)legality and a-legality. Section III focuses on normative pluralism and the development of juridical orders. Section IV discusses global regulation as an expansion of legal borderlands. Section V brings concluding remarks and summarizes the articles that follow.

\section{EXPLORING LEGAL BOUNDARIES: (IL)LEGALITY AND A-LEGALITY?}

In phenomenological terms, the discussion of legal borderlands is shaped by our experiences with concrete normative orders and our established expectations of behaviours in certain places and at certain times. ${ }^{8}$ Importantly, normativity depends on an inter-subjective perception of how individuals should behave and the complexity of social life opens opportunities for particular settings of negotiation of the symbolic meaning of human behaviour. Consider, for instance, the conduct of individuals who challenge the status quo by performing acts that are contrary to black letter law, while, at the same time, appealing to normative ideals of justice to persuade society that their action is legitimate. In this context, it is fair to consider that political protesters, social activists and counter-hegemonic leaders are renegotiating the legal borderlands and may transform established expectations of behaviours in society. If law regulates behaviour by setting subjective, material, spatial, and temporal boundaries, its "limits distinguish a legal order from the domain of what remains legally unordered for $\mathrm{it}^{\prime \prime} .{ }^{9}$ Examining these legal boundaries and limits, Hans Lindahl developed his concept of a-legality, that is, "strange behaviour and situations that, evoking another realm of practical possibilities, question the boundaries of (il)legality". ${ }^{10}$ According to him, "the legal boundaries challenged by a-legality manifest themselves as a fault line of normativity, and not merely as a limit that can be shifted by including what ought not to have been excluded, or by excluding what ought not to have been included" ${ }^{11}$ In terms of space and time, the law shapes a normative orientation by differentiating and

\footnotetext{
${ }^{8}$ Hans Lindahl, Fault Lines of Globalization: Legal Order and the Politics of A-Legality. (Oxford University Press 2013) 1.

${ }^{9}$ Idem 3.

${ }^{10}$ Idem.

${ }^{11}$ Idem.
} 
interconnecting behaviour in specific normative orientation assigned to places in articulations of past, present, and future. ${ }^{12}$

One particular example of a-legality comes from the orchestrated action of the chômeurs, a group of unemployed people who queue simultaneously in French supermarkets and process their goods at all the check-out points in groups of various individuals, but are planning to take their food without paying for it. ${ }^{13}$ This collective strategy of autoréduction is normally pursued during the highest shopping period of Christmas, so that their blockage of all supermarket register cashiers encourages the manager to simply allow them to leave the store with their goods without paying. ${ }^{14}$ Hans Lindahl suggests that the strategy of autoréduction calls the boundaries of the legal order into question, because the chômeurs challenge "how a certain legal orders determines who ought to do what, where, and when", creating indeterminacy within the legal order. ${ }^{15}$ According to him, legal borderlands are renegotiated and oughtplaces are reshaped in particular instances of land occupation, global trade, and the law of the cyberspace, just to name a few examples of potential a-legality. ${ }^{16}$ This thesis evolved recently into an idea that these normative geographical boundaries of law may be shaped and reshaped by the different modes of authority and dynamics of exclusion and inclusion typical of political disputes within the globalization of law. ${ }^{17}$ This brings us to a key aspect of legal borderlands: Normative pluralism.

\section{Normative PluRalism AND The DeVelopment OF UnOFFicial JURIDICAL ORDERS}

Key to unlock the question of legal borderlands is normative pluralism, born out of an opposition to legal centralism, that is, the notion that Law has a singular point of origin, the sovereign State. ${ }^{18}$ Pluralism intends to be comprehensive of the plethora of normative sources that shape societies and which legal centralism, in its exclusive attachment to public authority and institutionalized norm-production, fails to address: Indigenous laws, religious laws, commercial practices, local customary practices or other instances of social ordering that cannot be placed under the

\footnotetext{
12 Idem 18-21.

${ }^{13}$ Idem 30-31.

${ }^{14}$ Idem.

15 Idem 36.

${ }^{16}$ Idem 49-69.

17 See generally Hans Lindahl, Authority and the Globalisation of Inclusion and Exclusion. (Cambridge University Press 2018).

18 See, John Griffiths, 'What is Legal Pluralism?' (1986) 18(24) The Journal of Legal Pluralism and Unofficial Law 1.
} 
juridical hierarchy of the State. ${ }^{19}$ A central question that preoccupies normative pluralists is that of authority. Recognizing that authority is never congealed in an absolute singularity and that, instead, it is always contested by centrifugal claims, pluralists challenge the notion that a legal system must claim supremacy over other legal systems. ${ }^{20}$ According to Nicole Roughan, the pluralist goal is to develop an account of law that integrates different supremacy claims through a model of interdependence. ${ }^{21}$ As Sally Engle Merry highlights, it was not a coincidence that the scholars who first developed the field of normative pluralism had been working in post-colonial societies, in which pluralism was an unambiguous fact of life. ${ }^{22}$ Indeed, pluralism was meant to render 'the invisible' visible, acknowledging the rich and complex processes of social determination, both on the local level and on the global level.

This recognition of difference inevitably leads to the question of locating 'borders' or, in other words, locating a locus of authority that shapes social behaviour and cannot squarely fit under the positivistic paradigm of a unitary pyramid of norms set by public authority. How do we distinguish the legal from the non-legal? Does this distinction matter at all? An early, strong version of normative pluralism holds that 'all social control is more or less 'legal',, 23 constituting a direct attack on legal centralism. A more subtle and sophisticated account of distinguishing the legal from the non-legal comes from Gunther Teubner's work. According to Teubner, crucial in this distinction is the passage from function to code. ${ }^{24}$ Attempting to overcome the functionalism implied in 'normative orders', Teubner suggests that in order to understand when 'we stop speaking of law and find ourselves simply describing

${ }_{19}$ Brian Z Tamanaha, 'Understanding Legal Pluralism: Past to Present, Local to Global' (2008) 30 Sydney Law Review 375, 397.

${ }^{20}$ Paul S Berman, 'The Evolution of Global Legal Pluralism' in Roger Cotterrell and Maksymilian Del Mar (eds), Authority in transnational legal theory: Theorising across disciplines (Edward Elgar Publishing 2016) 152.

${ }^{21}$ Nicole Roughan, Authorities: Conflicts, Cooperation and Transnational Legal (Oxford University Press 2013) 157. This is in opposition to Joseph Raz's perspective of law as a comprehensive authority: "Since all legal systems claim to be supreme with respect to their subject-community, none can acknowledge any claim to supremacy over the same community which may be made by another legal system" Joseph Raz, The Authority of Law (2nd, Oxford University Press 2011) 119

22 Sally E Merry, 'Legal Pluralism' (1988) 22 Law \& Society Review 869, 847.

${ }^{23}$ Griffiths (n 19) 39.

${ }^{24}$ Gunther Teubner, 'The Two Faces of Janus: Rethinking Legal Pluralism' in Kaarlo Tuori, Zenon Bankowski and Jyrki Uusitalo (eds), Law and power: Critical and socio-legal essays (Legal semiotics monographs vol 6. Charles 1997) 127-128. 
social life, ${ }^{25}$ the idea that law has a particular function has to be left behind. Instead, law should be understood as a communicative process that follows the binary code of legal/illegal. ${ }^{26}$ Normative pluralism exists whenever phenomena of different exigencies are observed under the binary code of legal/illegal and thus produce normative expectations. This is a major shift in the perspective through which the delineation between legal and social norms is observed; it is, henceforth, not up to the arbitrary cognitive interests of the observer to delineate 'legal borderlands', but it is up to law itself, as a self-organising social practice, to produce its boundaries under the pressures of its social environment. ${ }^{27}$ Such an account moves the centre of legal production and development away from Parliament chambers, courtrooms, and administrative buildings, into the heart of society. Not unlike Teubner, Brian Tamanaha also presents a sociological and non-essentialist view of the law. According to his conventionalist perspective, 'law is whatever people identify and treat through their social practices as 'law" ${ }^{\prime 28}$

Marc Galanter and Manuel Gomez contributed to this non-essentialist perspective in their foreword to the Symposium 'Layers of Law and Social Order' at FIU College of Law on $24^{\text {th }}$ of October $2014^{29}$ by putting in a very provocative way that the legal academia is still waiting for Mendeleev. In contrast to the natural sciences and the precise conceptualization of matter, the symbolic representation of socio-legal normativity does not present "a clear distinction between the legal and the so-called non-legal dimensions" ${ }^{30}$ Categories like law in the books, higher law or official law are part of "an oversimplification of a multi-layered and intricate reality that resists easy depiction". ${ }^{31}$ For instance, Lawrence Friedman suggests that normative pluralism often consists of a dual system of high law and low law, in which one represents the view of the elites and the other represents the side of people with a lower social status. ${ }^{32}$ However, at least in the case of Ipanema Beach, the coexistence of people from different socio-economic backgrounds resulted in a combination of official and unofficial law and the emergence of socio-legal norms from the complex

\footnotetext{
${ }^{25}$ Merry (n 23) 878

${ }^{26}$ Teubner (n 25) 127-128

27 ibid 129

${ }^{28}$ Brian Z Tamanaha, 'A Non-Essentialist Version of Legal Pluralism' (2000) 27(2) Journal of Law and Society 296,313

${ }^{29} \mathrm{https} / / /$ ecollections.law.fiu.edu/lawreviewsymposia/LayersLawSocialOrder/ (checked in 17.09.2019).

${ }^{30}$ Marc Galanter and Manuel Gomez, 'Waiting for Mendeleev: The Tangle of Indigenous Law' (2014) 10 FIU Law Review 1.

${ }^{31}$ Idem.

${ }^{32}$ Lawrence Friedman, 'High Law and Low Law', (2014) 10 FIU Law Review 59.
}

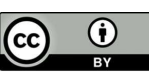


networks of beachgoers and their social tribes of yuppies, hippies and LGBT. ${ }^{33}$ On the other hand, Manuel Gomez demonstrated that an obviously illegal setting constituted by the invasion and occupation of the Tower of David in Caracas in Venezuela led to the emergence of a functioning normative order: "an example of a highly organized community with a functioning normative order that served its members better than the state or any other external system". ${ }^{34}$ Interestingly, the illegal origin of the occupation of a desert area for the Burning Man Festival in Nevada does not make any significant difference for the emergence of a highly organised and functioning normative order with a plethora of unofficial norms that regulate behaviour in the absence of the state official law. ${ }^{35}$ Likewise, the Brazilian favelas also develop their own unofficial law in parallel to the official state law, regardless of the illegality of the official invasion and land occupation. ${ }^{36}$

This sociological lens into normative pluralism presents itself as inherently democratic and inclusive. It empowers marginalized communities and minorities, often excluded from public deliberation and the centralized processes of normproduction, to regain a voice and to establish regimes of self-regulation that reflect their own autonomy. However, these are not the only social actors that are empowered by such an approach. The next section explores the expansion of legal borderlands in the context of global regulation.

\section{GLOBAL REGULATION AND THE EXPANSION OF THE LEGAL BORDERLANDS}

The participation of powerful corporate actors in the variety of sites of lawmaking or the construction of transnational financial governance beyond the State might serve to nuance, or complicate, this image. An example of how an inclusively pluralist approach, that is, an approach that avoids a strict delineation of 'legal borderlands', might end up accommodating corporate power is the autonomy of Credit Rating Agencies (CRAs) in issuing ratings based on self-developed methodologies. For instance, the EU regulatory framework allows CRAs to

33 Pedro R. Fortes, 'How Socio-Legal Norms Emerge Within Complex Networks: Law and (in)formality at Ipanema Beach', (2014) 10 FIU Law Review 193-203.

${ }^{34}$ Manuel A. Gómez, 'The Tower of David: Social Order in a Vertical Community' (2014) 10 FIU Law Review 218.

${ }^{35}$ Manuel A Gómez. 'Order in the Desert: Law Abiding Behavior at Burning Man'. (2013) 2 Journal of Dispute Resolution 349.

36 Boaventura de Sousa Santos. 'The law of the oppressed: the construction and reproduction of legality in Pasargada'. (1977) 12 Law \& Soc'y Rev 5. 
determine themselves the standards that they employ for the produced ratings, ${ }^{37}$ imposing on them only procedural requirements, such as disclosure requirements regarding rating methodologies. As CRA ratings can lead to chain reactions in the marketplace and shape social behaviour with significant consequences, there is little doubt that they possess a certain capacity for social ordering. Yet, they operate in a framework that allows them to remain a source of private ordering and the private gatekeepers of financial stability, with the accuracy of their methodologies being only under the scrutiny of other market actors. In a similar vein, Corporate Social Responsibility (CSR) codes involving commitment on corporate labour policy (e.g., regular and fair pay, health and safety conditions, etc.) are in many instances sources of transnational ordering, as they are incorporated in contract governance that binds actors across the supply chains of lead firms (subsidiaries, contractors, and subcontractors). In that sense, CSR codes could be interpreted as constituting autonomous 'legal bubbles' that homogenize regimes of production and economic coordination, defining the law on the ground beyond national regulations. ${ }^{38}$ Indeed, Teubner suggests that as global networks have emerged as the leading transnational constitutional subjects, CSR could be understood as emerging 'civil constitutions'. ${ }^{39}$ While the impact of such codes might be beneficial for labour rights transnationally, they remain the product of corporate self-regulation, without the underlying legitimacy of a democratic process or the co-authorship of those that are to benefit from such provisions.

These specific examples serve as concrete illustrations of Saskia Sassen's broader point that the governance of globalised capitalism necessarily bypasses the State and creates multiple loci of legal and regulatory agency. ${ }^{40} \mathrm{In}$ terms of the growth of law as a discipline, this expansion of the legal borderlands led to the recognition of global administrative law as a new field of study and research. ${ }^{41}$ The complexity of the administrative structure and the multiple loci for exercise of authority and power at global, continental, national, regional, and local level led to a reproduction of the

\footnotetext{
${ }_{37}$ Regulation (EU) No 513/2011 of the European Parliament and of the Council of 11 May 2011 amending Regulation (EC) No 1060/2009 on Credit Rating Agencies, art 23.

38 Tomaso Ferrando, 'Private Legal Transplant: Multinational Enterprises as Proxies of Legal Homogenisation' (2014) 5(1) Transnational Legal Theory 20, calling such enclosed areas of privately shaped law 'special legal zones'.

39 Gunther Teubner, 'The Corporate Codes of Multinationals: Company Constitutions Beyond Corporate Governance and Co-Determination' in Rainer Nickel (ed), Conflict of Laws and Laws of Conflict in Europe and Beyond: Patterns of Supranational and Transnational Juridification (Hart 2009) 204.

${ }^{40}$ See, Saskia Sassen, Territory, Authority, Rights (Princeton University Press 2006).

${ }^{41}$ Benedict Kingsbury, Nico Krisch, and Richard B. Stewart. 'The emergence of global administrative law'. (2004) 68 Law \& Contemporary. Problems, 15.
} 
circumstances of normative pluralism, including constitutional fragmentation..$^{42}$ On one hand, global administrative law deals with the bureaucratic management of international organizations and the functioning regimes of public and private transnational bodies - United Nations (UN), Federation International of Football Association (FIFA), and International Organization for Standardization (ISO), for instance. ${ }^{43}$ On the other hand, there is also a relevant normative corpus of global law constituted by public international law, lex sportiva and technical standards that constitute the nomos for the legal interpretation, application, and enforcement of global administrative law. ${ }^{44}$ This highlights how global regulation is exercised in the absence of the state and of public law. ${ }^{45}$ Importantly, the concept of law itself becomes disputed in the context of global administrative law as well as in the fragmentation of constitutional law and the development of unofficial juridical orders, especially in the context of private ordering and the absence of a unifying rule of recognition in the international community. ${ }^{46}$ Interestingly, the Brussels School of Jurisprudence coined an important working concept for the study of the contemporary global normative phenomena that are not recognized as legal according to the traditional standards of positive law: the Unidentified Normative Objects (UNOs). ${ }^{47}$ Their pragmatic approach to global law focused on the emergence of new forms of regulation and the consequences of globalization to cyberspace, climate change, finance \& accounting, technical standards and legal indicators. ${ }^{4}$ This idea of UNOs originated from an analogy with the Unidentified Flying Objects

${ }^{42}$ Nico Krisch, 'The pluralism of global administrative law'. (2006) 17(1) European Journal of International Law 247-278.

${ }_{43}$ Benedict Kingsbury, and Lorenzo Casini. 'Global administrative law dimensions of international organizations law'. (2009) 6(2) International Organizations Law Review 319-358. Particularly on the global regulation of football, see Pedro Rubim Borges Fortes. 'We The Fans: Should International Football Have Its Own Constitution'. (2014) 21 Southwestern Journal of International Law 63.

${ }^{44}$ Paul Craig, UK, EU and Global Administrative Law: Foundations and Challenges. (Cambridge University Press 2015).

${ }^{45}$ Sabino Cassese, 'Administrative Law Without the State? The Challenge of Global Regulation'. (2004) 37 NYU Journal of International Law and Politics, 663.

${ }^{46}$ See Benedict Kingsbury. 'The concept of 'law' in global administrative law'. (2009) 20.1 European Journal of International Law 23-57. See also Alexander Somek. 'The concept of 'law' in global administrative law: a reply to Benedict Kingsbury'. (2009) 20(4) European Journal of International Law 985-995.

${ }^{47}$ Benoit Frydman, A Pragmatic Approach to Global Law, Working Paper n. 06/2014, Perelman Center for Legal Philosophy, available at http://www.philodroit.be/IMG/pdf/bf_-_pragmatic_global_law__2014-6.pdf (checked in 17.09.2019).

${ }^{48}$ Idem 2. 
(UFOs) and established a theoretical justification for the study of all normative objects which are important for lawyering and the legal profession.

Global regulation develops in an interdisciplinary perspective and is shaped by context. Technical standards, for example, are influenced by scientific discourse, but also by power dynamics and economic potential in a setting of competition to define the rules of the game through the establishment of ISO guidelines with an embedded normative pattern of how a practice "ought to be". ${ }^{49}$ Likewise, legal indicators are also influenced by politics and influence regulatory competition between different states that transform their laws to increase their attractiveness to foreign direct investment and capital for socio-economic development. ${ }^{50}$ Technical standards and legal indicators are prodigious examples of the so-called "mathematical turn in law" and reveal how contemporary legal analysis is influenced by mathematical equations, statistical quantification, and numerical formulas. ${ }^{51}$

Overall, as transnationalism devolves significant decision-making to private actors, the state remains confined to the passive role of the guarantor to private, cross-border activity.52 This type of 'global legal pluralism', albeit fitting the description of Teubner and Tamanaha, appears constitutive of what David Grewal calls 'neoliberal legality', characterized by three border-related shifts: From sovereignty to governance, enabling an increasing juris-generative power of private actors and relying on networks of actors, rather than on crystallized hierarchies; from territory to norms, highlighting the functionalist orientation of transnational, plural orders that operate independently of territory; and from citizens to stakeholders, meaning that a principle of 'affected interests' is the prerequisite for participation in the process of norm-production, rather than the mere participation in a political community. ${ }^{53}$ In essence, this is a legality that deconstructs legal borderlands, relativizes the notion of bindingness, loosens the ties between 'law' and enforcement, and may present itself as a vehicle for depoliticizing the law, rendering certain arrangements impenetrable to societal pressures. The examples above are indicative:

\footnotetext{
${ }^{49}$ Tim Büthe, and Walter Mattli. The new global rulers: The privatization of regulation in the world economy. (Princeton University Press 2013); Walter Mattli and Tim Büthe. 'Setting international standards: technological rationality or primacy of power?' (2003) 56(1) World Politics 1-42.

${ }^{50}$ Kevin Davis E., Benedict Kingsbury, and Sally Engle Merry. 'Indicators as a technology of global governance'. (2012) 46(1) Law \& Society Review 71-104.

${ }^{51}$ Pedro Rubim Borges Fortes. 'How legal indicators influence a justice system and judicial behavior: the Brazilian National Council of Justice and 'justice in numbers"(2015) 47(1) The Journal of Legal Pluralism and Unofficial Law 39-55.

52 David S Grewal, 'Three Theses on the Current Crisis of International Liberalism' (2018) 25 Indiana Journal of Global Legal Studies 595, 616

53 ibid 620
} 
The ratings offered by private rating agencies and the codes of transnational corporations operate irrespectively of territory and have a relative bindingness for their addressees, even though they have no linkage to State power. They do not entail the threat of enforcement and, yet, they achieve regulatory outcomes. Finally, they may be susceptible to the pressures of certain stakeholders, such as investors, key market participants, and even consumers, but not to the democratic pressure of the citizenry.

Such a perspective into transnational orders and authority beyond the State warn against an unreflective celebration of legal pluralism. Yet, normative pluralism, beyond its attempt to describe the social fact of a multiplicity of normative orders, is also a normative project that develops in time. Paul Schiff Berman underscores that normative pluralism has lost the radical edge that characterized the early generations of pluralists, with current global normative pluralists and constitutional pluralists attempting to outline plausible sets of institutional arrangements and procedural mechanisms that could make dominant legal structures more pluralist. ${ }^{54}$ Nevertheless, this remains perforce a normative orientation. In this context, a onesize-fits-all answer to the conundrums legal borderlands pose appears unlikely. ${ }^{55}$ Because, while the recognition - and perhaps even institutionalization - of practices of marginalized communities may be a step forward in the struggle for social justice and structural transformation, ${ }^{56}$ emergent legal orders such as the ones described above can constitute highly hierarchical phenomena. The understanding of law as communication relies on informal societal pressures for the restriction of the actors whose influence and resources allow them to make more meaningful determinations of the binary legal/illegal. However, in that sense, autopoietic or conventionalist legal pluralism does not sufficiently address the social power behind the communicative processes or the conventions that determine whether a phenomenon is 'law'. The ambiguity of pluralism as a normative project arises from the fact that, while the acceptance of pluralism constitutes an emancipation from the confines of State power and a demystification of sovereignty, it also opens a door to a less restrained private power.

\footnotetext{
${ }^{54}$ Berman (n 21) 186

${ }^{55}$ In that direction, William Twining supports that the 'definitional stop' - drawing the line between law and non-law - should be examined in particular contexts, William Twining, General Jurisprudence: Understanding Law from a Global Perspective (Cambridge University Press 2009) 88-121, $362-75$.

${ }^{56}$ Berman (n 21) 159 offers the example of a liberal state creating a space for sharia law to be practised within certain enclaves, to the extent it does not infringe upon fundamental rights and it does not recognize or enforce such norms on non-members of the enclaves.
} 


\section{CONCLUDING REMARKS}

Finally, the theme of legal borderlands raises a series of normative questions. Recognizing the descriptive accuracy and the empirical reality of overlapping, contesting orders, what type of institutional arrangements are better attuned to principles of democratic participation, individual liberty, and socio-economic equality? Is fragmentation and distribution of authority among public and private actors fulfilling such a normative orientation? Are moderate positions of inclusion and recognition of contesting orders under the auspices of a centralized authority better suited to the demands of multicultural and economically liberal and globalized societies? Yet, it is questionable whether this recognition still allows us to speak of 'pluralism', considering that the incorporation of norms under state hierarchy appears contradictory with the original impetus of pluralism. Or, as a recent current of legal institutionalism seems to suggest, should law retain a direct connection with democratic legitimacy and, thus, with a susceptible to democratic pressures centralized public authority? ${ }^{57}$

The answer to all these questions is beyond the scope of the present essay, but these are important debates that are stimulated at the stream Exploring Legal Borderlands: Empirical and Interdisciplinary Approaches. In the last SLSA Conference in the University of Leeds, we organized four panels and discussed borderlands of political economy, digital societies, private networks, civil society and political discourse. The Brazilian Journal of Institutional Studies is publishing in this issue four of the twelve papers presented then.

In her article, Maureen Duffy explores the empirical and interdisciplinary borderlands of law in society by examining anti-migration narratives involving false claims that migrants are dangerous individuals. Her study "Wagging the Dog": Feigning Crisis in U.S. Anti-Migration Narratives to Create Crisis is a follow-up piece on her award-winning book Detention of Terrorism Suspects: Political Discourse and Fragmented Practices, which focuses on how strategic discourse is employed to create political narratives that facilitate the erosion of civil and political liberties. ${ }^{58}$ Her powerful article argues that harmful anti-migrant narratives have adverse effects on human rights and foundational norms, by describing a series of measures that harm migrants in the U.S. as part of a larger transnational trend.

Arwen Joyce's research also crosses transnational borders as she examines the regulation of low-wage temporary migrant workers in her article Working Across

${ }^{57}$ Simon Deakin and others, 'Legal Institutionalism: Capitalism and the Constitutive Role of Law' (2017) 45 Journal of Comparative Economics.

${ }^{58}$ Maureen Duffy, Detention of Terrorism Suspects: Political Discourse and Fragmented Practices. (Hart 2018). 
Borders: The Limits of Labour Law for Low-Wage Temporary Migrant Workers. The case studies of Singapore, Hong Kong and South Korea provide empirical evidence that conventional labour law remedies are insufficient to protect migrant workers. As a matter of fact, the Temporary Migrant Worker Programme (TMWP) may actually facilitate exploitation and disempowerment of individuals with precarious residence status, weak financial position and dependence of employers. Her conclusion is that these TMWPs should address the vulnerabilities of low-wage temporary migrant workers.

Dominic Birch also explores legal borderlands through empirical and interdisciplinary perspectives in the article Legal Pluralism in Early Modern England and Colonial Virginia, an original combination of historiography and normative pluralism. His research expands the scholarship on normative pluralism by using empirical evidence from the early modern period and recurring to it as a methodology for differentiating law as practice and theory. Interestingly, the paper focuses on the fragmentation of the colonial British legal system and reflects on the consequences of normative pluralism for ideas on the early British state and society. The conceptual vocabulary of normative pluralism facilitates a historical analysis of the interface between the legal and social spheres of English law in society.

Finally, Sapna Reheem Shaila also studies normative pluralism and the implementation of rule of law programmes, but her research focuses on the contemporary case study of East Timor. In her article Shifting the Legal Borderlands of Rule of Law Programs - Brazilian Cooperation Agency (ABC) and Public Defenders' Office in East Timor, she examines the emergence of 'South-South' cooperation in international legal assistance, using the case study of Brazilian legal assistance in East Timor. Using empirical data, the paper reveals the distinctive approaches of Brazilian international and shows how dominant rule of law reforms may push important local interests to the borders. As a contribution to empirical and interdisciplinary law and development literature, the article criticises how formal laws and institutions are copied as potential solutions for economic prosperity and stability without a proper assessment of context, because of the interests of donor nations to transfer their legal procedures and organizations to the recipient nations under the rule of law programs.

\section{REFERENCES}

Alexander Somek. 'The concept of 'law' in global administrative law: a reply to Benedict Kingsbury’. (2009) 20(4) European Journal of International Law 985995. 
Benedict Kingsbury. 'The concept of 'law' in global administrative law'. (2009) 20.1 European Journal of International Law 23-57.

Benedict Kingsbury, and Lorenzo Casini. 'Global administrative law dimensions of international organizations law'. (2009) 6(2) International Organizations Law Review 319-358.

Benedict Kingsbury, Nico Krisch, and Richard B. Stewart. 'The emergence of global administrative law'. (2004) 68 Law \& Contemporary. Problems, 15.

Benoit Frydman, A Pragmatic Approach to Global Law, Working Paper n. 06/2014, Perelman Center for Legal Philosophy, available at http://www.philodroit.be/IMG/pdf/bf_-_pragmatic_global_law_-_2014-6.pdf (checked in 17.09.2019).

Boaventura de Sousa Santos. 'The law of the oppressed: the construction and reproduction of legality in Pasargada'. (1977) 12 Law \& Soc'y Rev 5.

Boaventura de Sousa Santos, 'Law: A Map of Misreading. Toward a Postmodern Conception of Law' (1987) 14(3) Journal of Law and Society 279, 298.

Brian Z Tamanaha, 'A Non-Essentialist Version of Legal Pluralism' (2000) 27(2) Journal of Law and Society 296, 313.

Brian Z Tamanaha, 'Understanding Legal Pluralism: Past to Present, Local to Global' (2008) 30 Sydney Law Review 375, 397.

David S Grewal, 'Three Theses on the Current Crisis of International Liberalism' (2018) 25 Indiana Journal of Global Legal Studies 595, 616.

Gunther Teubner, 'The Corporate Codes of Multinationals: Company Constitutions Beyond Corporate Governance and Co-Determination' in Rainer Nickel (ed), Conflict of Laws and Laws of Conflict in Europe and Beyond: Patterns of Supranational and Transnational Juridification (Hart 2009) 204. 
Gunther Teubner, 'The Two Faces of Janus: Rethinking Legal Pluralism' in Kaarlo Tuori, Zenon Bankowski and Jyrki Uusitalo (eds), Law and power: Critical and socio-legal essays (Legal semiotics monographs vol 6. Charles 1997) 127-128.

Hans Lindahl, Authority and the Globalisation of Inclusion and Exclusion.

(Cambridge University Press 2018).

Hans Lindahl, Fault Lines of Globalization: Legal Order and the Politics of ALegality. (Oxford University Press 2013) 1.

John Griffiths, 'What is Legal Pluralism?' (1986) 18(24) The Journal of Legal Pluralism and Unofficial Law 1.

Kevin Davis E., Benedict Kingsbury, and Sally Engle Merry. 'Indicators as a technology of global governance'. (2012) 46(1) Law \& Society Review 71-104.

Lawrence Friedman, 'High Law and Low Law', (2014) 10 FIU Law Review 59.

Marc Galanter and Manuel Gomez, ‘Waiting for Mendeleev: The Tangle of Indigenous Law' (2014) 10 FIU Law Review 1.

Manuel A Gómez. ‘Order in the Desert: Law Abiding Behavior at Burning Man'. (2013) 2 Journal of Dispute Resolution 349.

Manuel A. Gómez, 'The Tower of David: Social Order in a Vertical Community' (2014) 10 FIU Law Review 218.

Maureen Duffy, Detention of Terrorism Suspects: Political Discourse and Fragmented Practices. (Hart 2018).

Nico Krisch, 'The pluralism of global administrative law'. (2006) 17(1) European Journal of International Law 247-278.

Nicole Roughan, Authorities: Conflicts, Cooperation and Transnational Legal (Oxford University Press 2013) 157. 
Paul Craig, UK, EU and Global Administrative Law: Foundations and Challenges. (Cambridge University Press 2015).

Paul S Berman, 'The Evolution of Global Legal Pluralism' in Roger Cotterrell and Maksymilian Del Mar (eds), Authority in transnational legal theory: Theorising across disciplines (Edward Elgar Publishing 2016) 152.

Pedro Rubim Borges Fortes. 'How legal indicators influence a justice system and judicial behavior: the Brazilian National Council of Justice and 'justice in numbers"'(2015) 47(1) The Journal of Legal Pluralism and Unofficial Law 39-55.

Pedro Rubim Borges Fortes. 'We The Fans: Should International Football Have Its Own Constitution'. (2014) 21 Southwestern Journal of International Law 63.

Pedro Rubim Fortes, 'How Socio-Legal Norms Emerge Within Complex Networks: Law and (in)formality at Ipanema Beach', (2014) 10 FIU Law Review 193-203.

Regulation (EU) No 513/2011 of the European Parliament and of the Council of 11 May 2011 amending Regulation (EC) No 1060/2009 on Credit Rating Agencies.

Sabino Cassese, 'Administrative Law Without the State? The Challenge of Global Regulation'. (2004) 37 NYU Journal of International Law and Politics, 663.

Sally E Merry, 'Legal Pluralism' (1988) 22 Law \& Society Review 869, 847.

Saskia Sassen, Territory, Authority, Rights (Princeton University Press 2006).

Simon Deakin and others, 'Legal Institutionalism: Capitalism and the Constitutive Role of Law' (2017) 45 Journal of Comparative Economics.

Tim Büthe, and Walter Mattli. The new global rulers: The privatization of regulation in the world economy. (Princeton University Press 2013).

Tomaso Ferrando, 'Private Legal Transplant: Multinational Enterprises as Proxies of Legal Homogenisation' (2014) 5(1) Transnational Legal Theory 20. 
Walter Mattli and Tim Büthe. 'Setting international standards: technological rationality or primacy of power?' (2003) 56(1) World Politics 1-42.

William Twining, General Jurisprudence: Understanding Law from a Global Perspective (Cambridge University Press 2009) 88-121, 362-75. 